\title{
PENINGKATAN PENGETAHUAN MASYARAKAT TENTANG PENGGUNAAN DAN PENGELOLAAN OBAT YANG RASIONAL MELALUI PENYULUHAN DAGUSIBU
}

\author{
Devi Ristian Octavia ${ }^{1}$, Irma Susanti ${ }^{2}$, Sri Bintang Sahara Mahaputra Kusuma Negara ${ }^{3}$ \\ ${ }^{1,2,3}$ Program Studi S1 Farmasi, Fakultas Ilmu Kesehatan, \\ Universitas Muhammadiyah Lamongan \\ E-mail: devioctavia1987@umla.ac.id
}

\begin{abstract}
In the era of National Health Insurance (JKN) which has an impact on increasing people's motivation to check health at health care facilities, so that efforts to get drugs are quite easy. But the increasing use of drugs has not been supported by public knowledge about how to consume and manage medicines at home. This community service activity aims to increase public knowledge about the proper use of drugs (rational) and procedures for storing and disposing of drugs that have been damaged or expired properly. The method used in this service is to increase knowledge about Get Use of Save and Dispose of Medication (DAGUSIBU) PKK cadres by counseling or educating and mentoring drug management at home. The knowledge gained by the community in this activity is expected to change people's behavior in managing medicines at home and rational use of drugs. The method used in this service is by approach. From the results of evaluation and monitoring of activities that have been carried out shows a positive result, namely an increase in knowledge about rational drug use and proper management of medicines at home.
\end{abstract}

Keywords: Dagusibu; Rational; Self-medication; Education; Knowledge

\section{PENDAHULUAN}

Pengobatan sendiri atau biasa disebut swamedikasi adalah salah satu upaya masyarakat menjaga kesehatannya sendiri (Harahap, Khairunnisa, \& Tanuwijaya, 2017). Konsumsi obat tanpa resep dalam praktik swamedikasi sudah dilakukan secara luas oleh masyarakat untuk mengobati berbagai kondisi penyakit yang ringan. Obat yang biasa digunakan dalam swamedikasi pada umumnya termasuk ke dalam golongan obat tanpa resep (Candradewi \& Kristina, 2017). Masyarakat Indonesia sudah terbiasa dalam menggunakan berbagai jenis obat-obatan untuk menyembuhkan penyakit, memelihara, ataupun sebagai suplemen dalam upaya menunjang aktifitas sehari-hari. Hal ini dapat terjadi karena berbagai faktor seperti perkembangan penyakit, produksi berbagai jenis obat-obatan dan suplemen serta 


\section{GEMASSIKA: Jurnal Pengabdian Kepada Masyarakat}

Vol. 4 No. 1 Mei 2020

mulai diberlakukannya jaminan kesehatan nasional yang memungkinkan masyarakat mendapatkan akses yang lebih mudah untuk mendapatkan pengobatan (Maziyyah, 2015).

Saat ini, masyarakat masih sering salah dalam hal mendapatkan, menggunakan, menyimpan dan membuang obat dengan benar. Hal tersebut dapat menyebabkan terjadinya hal yang tidak diinginkan dalam pengobatan seperti obat yang tidak bisa berfungsi optimal, obat yang salah cara penggunaannya, obat yang tidak disimpan secara benar dan pembuangan obat secara sembarangan. Hal yang tidak diinginkan tersebut tentu saja dapat merugikan bagi masyarakat saat menggunakan obat (Purwidyaningrum, Peranginangin, Mardiyono, \& Sarimanah, 2019).

Perilaku penggunaan obat untuk menyembuhkan penyakit ringan di masyarakat sebagai upaya swamedikasi (pengobatan sendiri) sangat tinggi. RISKESDAS (2013) telah mendata sebanyak $35,2 \%$ keluarga di Indonesia menyimpan obat untuk swamedikasi. Hasil penelitian menunjukkan bahwa penggunaan obat yang tidak rasional mencapai lebih dari 50\% di masyarakat (WHO dalam Harahap et al., 2017)). Hasil penelitian di Kota Penyabungan mengungkapkan bahwa penggunaan obat untuk swamedikasi 59,4\% rasional dan 40,6\% tidak rasional. Pada kenyataannya, pengobatan sendiri bisa menjadi sumber masalah terkait obat (Drug related problem) karena terbatasnya pengetahuan mengenai obat dan penggunaannya. Penelitian yang telah dilakukan menunjukkan bahwa mayoritas tingkat pengetahuan pasien terhadap penggunaan obatuntuk swamedikasitergolong sedang. Penggunaan obat swamedikasi yang tidak rasional mencapai 40,6\% (Harahap et al., 2017). Swamedikasi menjadi pilihan yang diambil masyarakat sebagai upaya untuk meningkatkan keterjangkauan pengobatan masyarakat seharusnya memerlukan pedoman yang terpadu supaya tidak terjadi kesalahan pengobatan (medication error) (Restiyono, 2016). Dalam melakukan swamedikasi harus sesuai dengan penyakit yang diderita. Prakteknya harus memenuhi kriteria penggunaan obat yang rasional, yaitu tepat pemilihan obat, tepat dosis obat, tepat dengan kondisi pasien, tidak adanya efek samping yang fatal, tidak ada kontraindikasi pada penderita, tidak ada interaksi obat dengan makanan atau obat yang lain, dan tidak ada polifarmasi. Masyarakat di desa Madulegi Kecamatan Sukodadi memiliki akses yang cukup baik terhadap kesehatan, termasuk di dalamnya penggunaan obat, baik obat yang 
harus menggunakan resep dokter maupun obat bebas dan obat bebas terbatas yang bisa dibeli tanpa resep dokter. Saat ini Indonesia berada pada era Jaminan Kesehatan Nasional (JKN) yang berimbas pada keinginan masyarakat untuk memeriksakan kesehatan pada fasilitas layanan kesehatan semakin meningkat, sehingga upaya dalam mendapatkan obat pun cukup mudah. Namun penggunaan obat yang semakin meningkat ini belum didukung dengan peningkatan pengetahuan masyarakat tentang cara konsumsi dan pengelolaan obat di rumah. Dalam pengelolaan obat di rumah masyarakat desa Madulegi Kecamatan Sukodadi banyak yang belum mengerti bagaimana cara menyimpan dan membuang obat yang benar. Masyarakat banyak yang menyimpan obat sirup ataupun eliksir dalam kulkas dengan alas an agar obat lebih awet. Pemberian informasi yang benar terkait penggunaan obat menjadi kebutuhan masyarakat agar terhindar dari dampak buruk kesehatan diri maupun lingkungan. Menurut Dwi Ajeng Eli Ananda, Liza Pristianty, \& Hidajah Rachmawati, (2013) Masyarakat membutuhkan pengetahuan yang baik untuk melakukan swamedikasi yang benar.

Penelitian yang dilakukan oleh Safitri (2016) membuktikan bahwa penyuluhan atau edukasi mampu meningkatkan pengetahuan obat masyarakat secara signifikan. Penelitia lain dilakukan oleh Yati, Hariyanti, \& Lestari, (2018) menyatakan bahwa pelatihan pengelolaan obat dengan metode ceramah dilanjutkan dengan Tanya jawab dan diskusi mampu menunjukkan peningkatan pengetahuan dan pemahaman para guru penanggung jawab UKS di wilayah Jakarta terhadap DAGUSUBU.

Rendahnyarasa keingintahuan masyarakat mengenai penggunaan obat secara benar sangatlah berbahaya. Pengelolaan obat di masyarakat mulai dari prosedur mendapatkan, menggunakan, menyimpan, dan membuang sisa obat tidak boleh dianggap remeh, karena jika salah melakukan pengelolaa nobat, maka akan berakibat sangat fatal bagi diri kita sendiri atau konsumen obat. Dampak lain dari kesalahan pengelolaan obat akan terlihat pada lingkungan. Pencemaran lingkungan karena pembuangan obat yang sembarangan akan menyebabkan keseimbangan ekosistem terganggu yang pada akhirnya juga menyebabkan kerugian bagi masyarakat. Oleh karena itu penting untuk mengedukasi masyarakat agar pengetahuan tentang penggunaan dan pengelolaan obat yang baik dapat meningkat. Program Studi Farmasi Universitas Muhammadiyah Lamongan sebagai kader tenaga kefarmasian yang 
merupakan sumber informasi obat dapat melakukan pengabdian kepada masyarakat dengan metode edukasi atau penyuluhan untuk meningkatkan pengetahuan masyarakat tentang penggunaan dan pengelolaan obat yang tepat.

\section{MASALAH, TARGET DAN LUARAN}

Dari survey awal yang telah dilakukan, tim pengabdian kepada masyarakat mengidentifikasi bahwa masalah yang dihadapi oleh masyarakat desa Madulegi Kecamatan Sukodadi Lamongan adalah rendahnya pengetahuan tentang penggunaan obat yang rasional, masyarakat kurang memahami obat apa saja yang boleh dibeli tanpa resep dan harus memakai resep dokter selain itu, masyarakat juga kurang memahami pengelolaan obat di rumah seperti cara menyimpan obat dengan benar dan membuang obat yang telah rusak atau kadaluarsa.

Target luaran dari kegiatan pengabdian masyarakat ini adalah untuk meningkatkan pengetahuan masyarakat tentang definisi umumdanklasifikasiobat,memahamiberbagai macam sediaan obat dan cara penggunaannya yang tepat (rasional), selain itu masyarakat mampu memahami tata cara penyimpanan dan pembuangan obat yang telah rusak atau kadaluarsa dengan tepat melalui penyuluhan atau edukasi DAGUSIBU. Pengetahuan yang di dapatkan oleh masyarakat dalam kegiatan ini diharapkan dapat merubah perilaku masyarakat dalam pengelolaan obat di rumah dan penggunaan obat secara rasional.

\section{METODE PELAKSANAAN}

Pelaksanaan Kegiatan

Kegiatan pengabdian masyarakat ini dilaksanakan di Desa Madulegi Kecamatan Sukodadi Lamongan dan dihadiri oleh 36 orang ibu PKK pada bulan Desember 2018 oleh dosen prodi Farmasi Universitas Muhammadiyah Lamongan dalam upaya pelaksanaan salah satu pilar dalam tridarma perguruan tinggi yaitu pengabdian kepada masyarakat. Kegiatan pengabdian pada masyarakat ini diawali dengan identifikasi masalah yang dialami oleh masyarakat yaitu dilakukan dengan cara pendekatan kepada masyarakat di desa Madulegi dan melakukan wawancara untuk menggali informasi tentang pengetahuan mereka terkait penggunaan obat yang benar, selain itu tim pengabdian masyarakat juga melakukan wawancara terhadap karyawan apotek di desa Madulegi untuk menggali informasi tentang pola penggunaan obat pada masyarakat di 
desa tersebut. Dari identifikasi yang telah dilakukan kemudian membuat rencana pemecahan masalah yang sedang di hadapi tersebut dengan cara diskusi dengan kader PKK dan menyusun kegiatan penyuluhan yang dilakukan dengan metode ceramah dan menggunakan alat bantu berupa leaflet atau brosur DAGUSIBU.

Materi yang disampaikan dalam penyuluhan yaitu sosialisasi tentang definisi umum dan golongan obat, penjelasan tentang berbagai macam sediaan obat dan cara menggunakan obat yang rasional, yaitu meliputi aspek 4 Tepat dan $1 \mathrm{~W}$ yaitu Tepat Indikasi, Tepat Dosis, Tepat Kondisi Pasien, Tepat Penggunaan dan Waspada pada Efek Samping Obat. Kemudian dijelaskan pula mengenai tata cara penyimpanan dan pembuangan obat yang telah rusak atau kadaluarsa dengan benar agar tidak mencemari lingkungan atau disalahgunakan oknum yang tidak bertanggung jawab.

Dalam proses monitoring dan evaluasi, indikator keberhasilan program pengabdian dilihat dari bagaimana respon dari peserta ketika tim pengabdian menyampaikan materi. Tim penyaji membuat berbagai umpan balik, sehingga peserta dapat aktif bertanya dan menjawab. Selain itu peserta di beri questioner pre-test dan post-test untuk megetahui perbandingan pengetahuan peserta sebelum dan sesudah diberi penyuluhan DAGUSIBU. Tindak lanjut dari kegiatan ini adalah pendampingan kader PKK dalam pengelolaan obat di rumah, dimonitoring selama satu bulan.

\section{HASIL PEMBAHASAN}

Kegiatan pengabdian kepada masyarakat oleh dosen Farmasi Universitas Muhammadiyah Lamongan ini diawali dengan survey awal terkait permasalahan yang dialami oleh masyarakat desa Madulegi khususnya ibu-ibu yang tergabung dalam kegiatan PKK. Tim pengabdian menggali informasi mengenai pengetahuan kader PKK dalam menggunakan obat dengan memberikan pretest kepada kader PKK. Adapun hasil pretest mengenai obat kader PKK tersebut dapat dilihat pada gambar 1 .

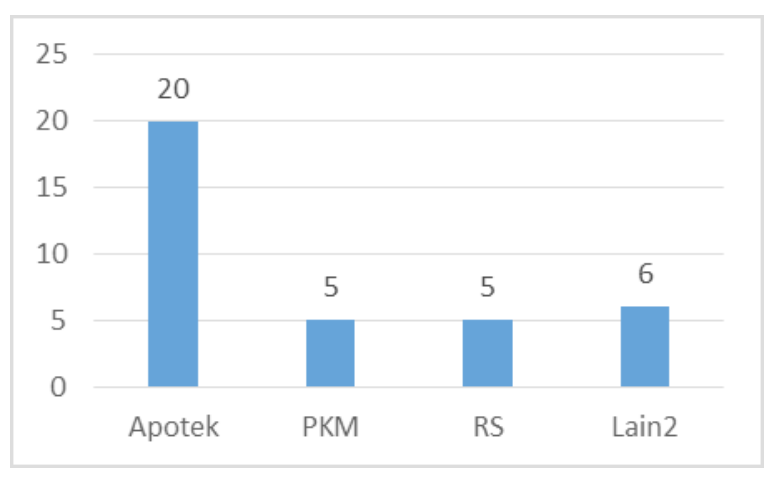

Gambar 1.

Cara masyarakat dalam mendapatkan obat 
GEMASSIKA: Jurnal Pengabdian Kepada Masyarakat

Vol. 4 No. 1 Mei 2020

Gambar 1 menunjukkan bahwa masyarakat terutama kader PKK di desa Madulegi lebih dari setengah 20 dari 36 orang atau 55\% mendapatkan obat dari apotek. Hal ini berarti menggambarkan tingginya perilaku swamedikasi dalam masyarakat dalam mengatasi keluhan kesehatan yang dirasakannya.

Hasil dari pretest tentang DAGUSIBU saat survey awal dapat dilihat pada gambar 2 .

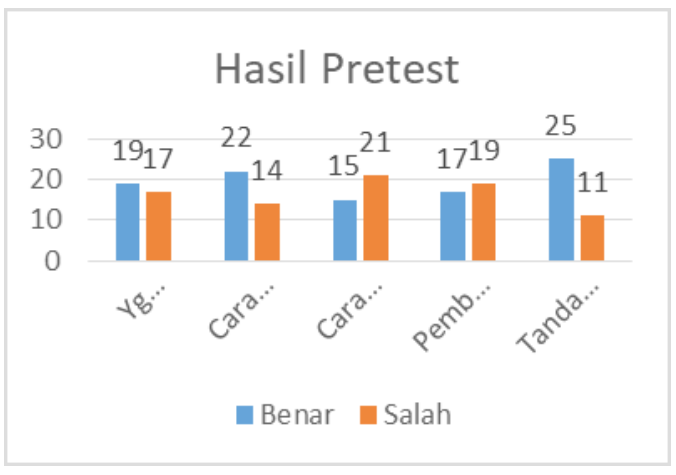

\section{Gambar 2.}

Hasil Pretes Peserta sebelum dilakukan penyuluhan

Dari hasil pretest terhadap pengetahuan mengenai DAGUSIBU (Gambar 2) menunjukkan bahwa masih banyak masyarakat yang belum mengetahui tentang DAGUSIBU.

Adapun pertanyaan yang dikeluarkan dalam pretest berisi tentang pengetahuan masyarakat dalam penggunaan dan pengelolaan obat, seperti : Apa yang harus diperhatikan saat membeli obat; Bagaimana cara penggunaan obat yang benar; Bagaimana cara penyimpanan obat yang benar; Bagaimana cara pembuangan obat yang benar dan apa tanda-tanda obat yang telah rusak. Pertanyaan yang diajukan merupakan pertanyaan open ended question. Alasan pemilihan pertanyaan terbuka ini adalah agar mempermudah tim pengadian untuk mengeksplor permasalahan yang dialami oleh peserta pengabdian kepada masyarakat ini. Dengan membuat pertanyaan tipe open ended question diharapkan dapat menggali semua pendapat, keinginan dan pengetahuan dari responden atau peserta pengabdian masyarakat ini. Walaupun pertanyaan yang digunakan dalam questioner ini merupakan pertanyaan terbuka, namun disediakan pilihan jawaban untuk mempermudah masyarakat dalam menjawab pertanyaan.

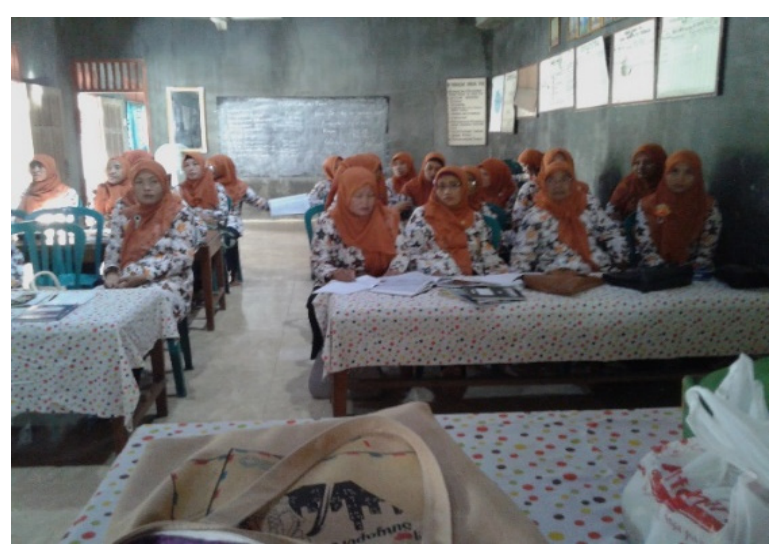

Gambar 3. Kader PKK sebagai Peserta

DAGUSIBU obat merupakan singkatan dari, DApatkan, GUnakan,SImpan, dan 
BUang obat dengan benar. Kegiatan ini selaras dengan program yang dicanangkan oleh Ikatan Apoteker Indonesia (IAI) melalui gerakan keluarga sadar obat (GKSO) yang telah di sosialisasikan sejak tahun 2014. Kegiatan ini merupakan upaya profesi Apoteker dalam meningkatkan kesadaran masyarakat dan mencerdaskan masyarakat dalam berperilaku sehat, khususnya terkait dengan obat. Masyarakat dalam upaya pemeliharaan kesehatannya seringkali melakukan swamedikasi, yaitu mengatasi keluhan penyakit yang dideritanya dengan membeli obat-obatan atas inisiatif sendiri tanpa berkonsultasi kepada dokter atau tenaga kesehatan terlebih dahulu. Selain itu kegiatan pengabdian masyarakat ini juga sesuai dengan program pemerintah yang dicanangkan oleh Mentri Kesehatan Nila Moloek (2015) yaitu Gema Cermat. Gerakan ini dilandasi karena rendahnya pemahaman masyarakat akan penggunaan obat. Gema Cermat adalah program bersama antara pemerintah dan masyarakat dalam suatu rangkaian kegiatan untuk mewujudkan kepedulian, kesadaran, pemahaman dan keterampilan masyarakat dalam menggunakan obat secara tepat dan aman.

Menurut penelitian yang dilakukan oleh Arrais et al., (2016) di Brazil mengungkapkan bahwa penggunaan obat tanpa resep dalam upaya swamedikasi sebesar $65,5 \%$. Setelah dianalisis didapatkan informasi bahwa wanita lebih sering melakukan swamedikasi daripada laki-laki, dimana obat yang paling banyak digunakan adalah golongan analgesik. Dalam penelitian tersebut juga menyatakan bahwa penggunaan obat-obatan tanpa resep harus memperhatikan kemungkinan resiko yang terjadi. Hal ini selaras dengan tujuan kegiatan pengabdian ini yaitu mengedukasi pasien dalam pengelolaan obat yang tepat dan penggunaan obat yang rasional.

Kegiatan pengabdian masyarakat ini dimulai dengan diskusi tentang perilaku swamedikasi yang biasa dilakukan oleh masyarakat di desa Madulegi. Dari hasil diskusi yang telah dilakukan didapatkan informasi bahwa hampir semua peserta $(85 \%)$ menyimpan obat-obatan di rumah sebagai persediaan dalam upaya melakukan swamedikasi ketika dirinya atau anggota keluarganya mengalami gangguan kesehatan. Upaya swamedikasi dilakukan oleh masyarakat sebelum memerikaskan keluhan kesehatannya kepada tenaga kesehatan karena dinilai lebih hemat waktu, tenaga dan biaya. Hal serupa juga dilaporkan oleh Pons et al (2017) bahwa 73,8\% masyarakat menyimpan obat di rumah sebagai persediaan 
untuk menangani keluhan kesehatan mereka, dan sebesar 35,5\% memakai sisa obat anggota keluarga lain yang memiliki keluhan yang sama.

Kegiatan Sosialisasi dimulai dengan pembukaan kegiatan penyuluhan oleh kepala desa Madulegi dan dilanjutkan diskusi mengenai pengetahuan peserta akan DAGUSIBU sembari peserta dibagikan brosur atau leaflet DAGUSIBU. Adapun brosur atau leaflet yang dibagikan kepada peserta dapat dilihat pada gambar 4 .
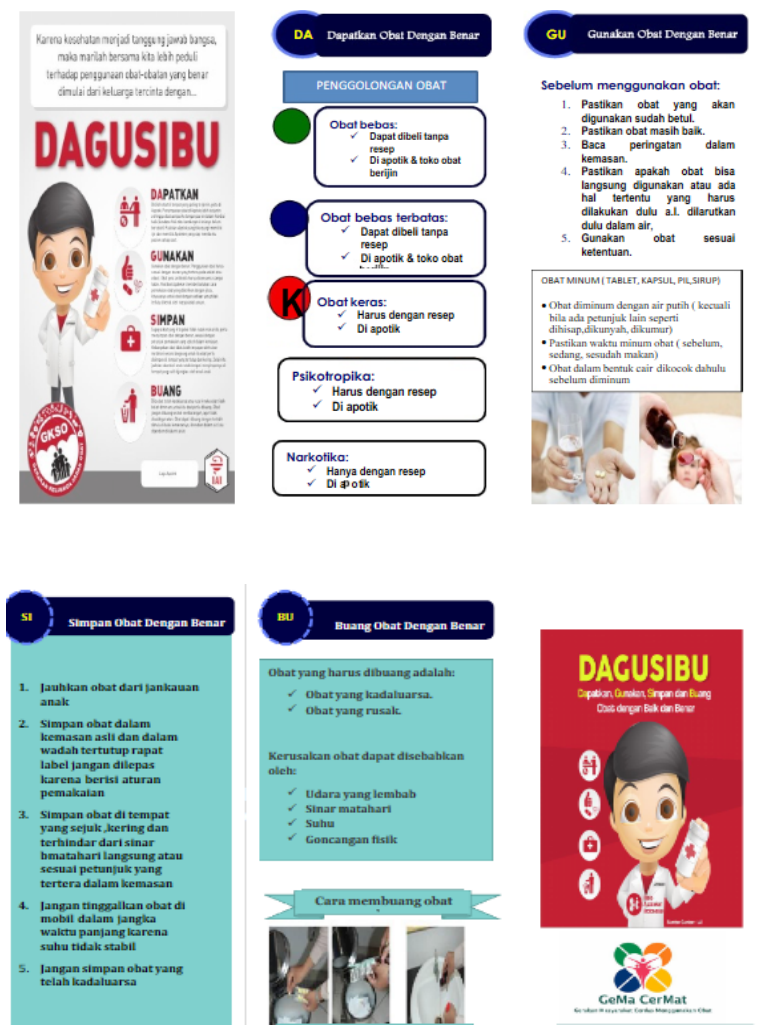

DACUSIBU

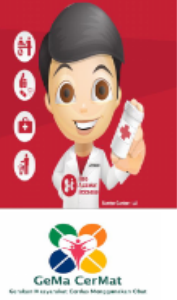

Gambar 4. Leaflet DAGUSIBU

Selanjutnya pemateri menjelaskan tentang DAGUSIBU.

\section{Dapatkan Obat dengan Benar}

Cara mendapatkan obat yang baik, adalah di apotek atau toko obat berizin. Pengelolaan obat di Apotek lebih baik dan terjamin keaslian dan keamanannya, sehingga obat sampai ke tangan pasien dalam kondisi baik (keadaan fisik dan kimianya belum berubah). Masyarakat juga dihimbau untuk memastikan apotek atau toko obat yang dikunjungi memiliki ijin resmi dan memiliki tenaga kefarmasian yang siap membantu setiap saat untuk mendapatkan informasi obat secara lengkap guna mendapatkan manfaat yang optimal.

\section{Gunakan Obat dengan Benar}

Penjelasan selanjutnya adalah cara menggunakan obat dengan benar. Diawali dengan menjelaskan tentang golongan obat obat. Berdasarkan Peraturan PerUndang-Undangan, obat terbagi menjadi 4 golongan yaitu : Obat Bebas dengan logo berwarna Hijau dengan lingkaran hitam, Obat Bebas Terbatas berlogo biru dengan lingkaran hitam, biasa juga disebut dengan obat daftar W, Obat Keras dengan logo merah dan huruf "K" dibagian tengah lingkaran hitam, obat ini juga basa disebut dengan obat daftar 
“G”, selanjutnya adalah obat Narkotika berlogo palang merah dengan lingkaran hitam. Diantara golongan obat tersebut, obat yang bisa dipakai dalam pelayanan swamedikasi adalah obat-obat golongan obat bebas dan obat bebas terbatas, juga obat keras yang masuk daftar Obat Wajib Apotek (OWA). Sedangkan untuk obat keras non OWA dan golongan Narkotika harus dibeli dengan menggunakan resep dari dokter. Penting bagi masyarakat untuk mengetahui penggolongan obat karena golongan obat ini merupakan dasar dari upaya melakukan swamedikasi. Seperti yang dikemukakan oleh Restiyono, (2016) bahwa swamedikasi adalah cara yang telah biasa dilakukan masyarakat terutama ibu rumah tangga dalam pengobatan beberapa penyakit ringan sekarang ini. Yang perlu di perhatikan disini adalah penekanan bahwa masyarakat hanya bisa melakukan swamedikasi dalam mengatasi keluhan kesehatan yang ringan, sehingga penggunaan obat pun hanya dalam jangka waktu yang pendek. Perlu diperhatikan juga ketika mendapatkan obat dari apotek atau pelayanan kesehatan lain masyarakat hendaknya menanyakan seluk beluk mulai dari kandungan, kegunaan, cara pemakaian dan Efek samping obat yang akan dikonsumsi. Masyarakat harus benar-benar memahami bahwa obatobat yang bisa dipakai dalam praktik swamedikasi adalah golongan obat bebas dan bebas terbatas, karena kedua obat ini relative aman digunakan dan efek sampingnya kecil jika digunakan dalam dosis dan aturan yang tepat. Sedangkan jika akan mengkonsumsi obat golongan OWA dalam praktik swamedikasi hendaknya masyarakat betul-betul memahami khasiat, kandungan, cara penggunaan dan resiko efek samping dari obat yang akan dikonsumsi. Masyarakat dihimbau untuk cerdas menggunakan obat dengan berkonsultasi kepada apoteker dan mendapatkan informasi sebanyak-banyaknya terkait obat yang akan dikonsumsinya. Apoteker adalah salah satu tenaga kesehatan yang memiliki keahlian di bidang obat dan informasi obat. Apoteker mempunyai keahlian dan kewenangan da;am bidang kefarmasian baik di apotek, rumah sakit, industri, pendidikan, dan bidang lain yang berkaitan dengan kefarmasian, sehingga penting bag masyarakat untuk berkonsultasi kepada Apoteker terlebih dahulu sebelum memutuskan untuk mengkonsumsi obat tertentu agar 
pengobatan yang dilakukan mendapat efek terapi yang optimal.

Pengguaan obat harus sesuai dengan aturan yang tertera pada wadah atau etiket. Masyarakat dihimbau untuk membaca informasi yang tertera pada brosur atau kemasan obat terlebih dahulu sebelum mengkonsumsinya. Hal tersebut bertujuan agar masyarakat mempunyai informasi yang jelas terkait kandungan dan cara penggunaan obat yang akan dikonsumsi, sehingga penggunaan obat sesuai atau rasional. Menurut World Health Organization (WHO), (2012) Pengguanaan obat yang tepat atau biasa disebut dengan pengobatan yang rasional adalah jika pasien mendapatkan obat yang tepat untuk kebutuhan klinis, dalam dosis yang cukup, untuk jangka waktu yang sesuai, dan dengan biaya yang terjangkau baik untuk individu maupun masyarakat. Penggunaan obat dkatakan rasioanal jika memehi kaidah 4T 1W, yaitu Tepat Penggunaan, Tepat Pemakaian, Tepat Pemilihan Obat, Tepat Dosis, Tepat Kondisi Pasien dan Waspada terhadap Efek Samping. Dalam penjelasan materi terkait pengguanan obat ini, penyuluh memberikan contoh misalkan Obat jenis antibiotika harus dikonsumsi sampai habis untuk menghindari terjadinya resistensi, dan diminum sesuai dengan petunjuknya, misalkan petunjuknya adalah 3x1, maka berarti diminum tiap 8 jam sekali. Selain itu dijelaskan pula kepada masyarakat bahwa penggunaan antibiotika harus sesuai petunjuk dan peresepan dari dokter, karena antibiotika termasuk kedalam golongan obat keras. Penjelasan tentang penggunaan antibiotic ini menjadi penekanan bagi pemateri mengingat tingginya angka resistensi bakteri akibat penggunaan antibiotika yang tidak tepat. Menurut Restiyono (2016) Swamedikasi antibiotik memiliki dampak secara medis, yaitu dapat terjadi resistensi yang dapat memperparah penyakit. Karena tidak semua penyakit memerlukan antibiotik. Dalam penelitian tersebut juga diungkapkan bahwa 56\% ibu-ibu menyimpan antibiotika dirumah dan mengkonsumsinya kembali ketika terjadi keluhan kesehatan dengan alasan proseskesembuhan penyakitmenjadilebih cepat dengan mengkonsumsi antibiotic. Hal tersebut menjadai tantangan bagi pemateri untuk meluruskan pengetahuan masyarakat tentang antibiotika sehingga pengguanaan antibiotika bisa diminimalisasikan dengan harapan 
mampu menurunkan pula angka resistensi mikroba. Penjelasan lain pemateri memberiakan contoh penggunaan obat untuk mengatasi keluhan nyeri dan demam, maka diberikan analgesic antipiretik misalnya paracetamol, maka obat tersebut dikonsumsi hanya jika timbul keluhan atau gejala panas saja, ketika sudah tidak nyeri atau demam, maka pengobatan harus dihentikan.

Selanjutnya pemateri dibantu dengan tim pengabdian yang lain memperagakan cara penggunaan obat yang tepat, misalnya pada sediaan tetes mata, tetes telinga dan tetes hidung, yang merupakan sediaan steril, maka sebelum menggunakannya, hendaknya cuci tangan terlebih dahulu dan diusahakan ujung kemasan tidak boleh tersentuh atau terkena bagian tubuh, karena akan mempengaruhi sterilitasnya.

\section{Simpan Obat dengan Benar}

Materi selanjutnya yang disampaikan kepada tim penyuluh adalah Penyimpanan Obat. Hal ini juga berkaitan dengan pengelolaan obat di rumah. Untuk menghindari kerusakan obat, maka diperlukan menyimpan obat dengan benar, sesuai petunjuk penyimpanan yang terdapat pada kemasan atau leaflet. Menurut Lutfiyati1, Fitriana Yuliatuti, \& Dianita (2017). Penyimpanan merupakan hal yang harus diperhatikan karena kualitas produk bisa rusak jika penyimpanannya tidak tepat. Penyimpanan obat yang tepat harus memperhatikan suhu, cahaya, kelembaban dan oksigen tempat penyimpanan. Semua sediaan obat harus disimpan dalam suhu yang sesuai, untuk menhindari terjadinya percepatan kerusakan obat akibat panas atau perubahan suhu yang ekstrim. Secara umum, obat dapat disimpan pada suhu ruangan $\left(25^{\circ} \mathrm{C}\right)$ serta tidak melebihi $30^{\circ} \mathrm{C}$ atau kurang dari $15^{\circ} \mathrm{C}$. Produk yang sensitif terhadap perubahan cahaya, biasanya akan disimpan dalam botol/ kemasan berwarna gelap. Maka dari itu apabila mendapatkan obat yang diberikan dalam wadah gelap, jangan pindahkan obat tersebut ke wadah lain yang transparan atau bening yang berakibat isi dari obat tersebut akan terkena cahaya secara langsung. Untuk melindungi obat dari kondisi dengan kelembapan tinggi, biasanya dipilih wadah yang terbuat dari kaca atau plastik. Sebaiknya untuk obat ini disimpan di kotak obat yang terlindung dari sinar matahari langsung dan tidak bisa dijangkau oleh anak - anak. Obat 
memiliki stabilitas yang berbeda-beda tergantung dari karakteristik masingmasing bahan obat. Kondisi penyimpanan harus menyesuaikan terhadap stabilitas masing-masing obat. Ada obat yang harus disimpan pada suhu ruang dan ada yang harus disimpan dalam lemari pendingin (Yati et al., 2018). Obat juga tidak boleh disimpan di dalam kulkas yang bercampur dengan bahan makanan karena dikhawatirkan akan terjadi kontaminasi silang antara zat kimia dalam obat dengan makanan yang terdapat dalam kulkas yang berakibat pada efek yang tidak baik dari makanan ataupun dari obat.

Selain itu yang perlu diperhatikan adalah lama penyimpanan obat. Lama penyimpanan obat tergantung dari kandungan dan cara menyimpannya. Obat yang mengandung cairan akan mengalami reaksi peruraian paling cepat, hal ini disebabkan karena bakteri dan jamur dapat tumbuh baik di lingkungan lembab (cair). Dalam obat-obatan biasanya ada kandungan zat pengawet, yang dapat merintangi pertumbuhan bakteri dan jamur. Akan tetapi bila wadah sudah dibuka, maka zat pengawetpun tidak mampu menghindari kerusakan obat secara keseluruhan karena kemasan tidak tertutup rapat lagi. (Purwidyaningrum et al., 2019).

Tabel 1.

Masa kadaluwarsa obat sejak tanggal dibuka

\begin{tabular}{|c|c|c|c|}
\hline No & $\begin{array}{l}\text { Bentuk } \\
\text { Sediaan }\end{array}$ & $\begin{array}{c}\text { Waktu } \\
\text { Kadaluarsa } \\
\text { setelah } \\
\text { dibuka }\end{array}$ & Alasan \\
\hline 1 & krim & 1 bulan & $\begin{array}{l}\text { Kandungannya } \\
\text { terpapar } \\
\text { dan dapat } \\
\text { terkontaminasi }\end{array}$ \\
\hline 2 & $\begin{array}{l}\text { Krim } \\
\text { dalam tube }\end{array}$ & 3 bulan & $\begin{array}{l}\text { Wadah } \\
\text { tertutup, } \\
\text { isi tidak } \\
\text { langsung } \\
\text { terpapar } \\
\text { lingkungan } \\
\text { luar }\end{array}$ \\
\hline 3 & Tablet & 2 bulan & \\
\hline 4 & $\begin{array}{l}\text { Tablet/Cairan } \\
\text { yang } \\
\text { dimasukkan } \\
\text { dalam } \\
\text { kemasan }\end{array}$ & 6 bulan & $\begin{array}{l}\text { Tidak } \\
\text { tergantung } \\
\text { pada } \\
\text { stabilitas }\end{array}$ \\
\hline 5 & $\begin{array}{l}\text { Tetes mata/ } \\
\text { hidung/ } \\
\text { telinga }\end{array}$ & 1 bulan & $\begin{array}{l}\text { Rekomendasi } \\
\text { manufaktur }\end{array}$ \\
\hline 6 & Inhaler & $\begin{array}{c}\text { Berdasar } \\
\text { tanggal } \\
\text { kadaluarsa }\end{array}$ & $\begin{array}{l}\text { Wadah } \\
\text { tertutup }\end{array}$ \\
\hline
\end{tabular}

4. Buang Obat dengan Benar

Materi terakhir adalah Buang Obat dengan benar. Bila obat sudah kadaluarsa atau rusak, maka obat tidak boleh dikonsumsi lagi, maka harus dibuang. Obat tidak boleh dibuang sembarangan supaya tidak disalahgunakan. Sebelum obat dibuang, terlebih dahulu dibuka kemasannya, direndam dalam air, lalu 
dipendam di dalam tanah. Tahapan dalam membuang obat menurut Purwidyaningrum et al., (2019) adalah sebagai berikut:

a. Pertama, lihat instruksi pembuangan yang dianjurkan untuk obat tersebut.

b. Obat-obatan tertentu ada yang disarankan untuk dibuang ke toilet atau saluran air. Hal tersebut merupakan hasil pertimbangan antara Badan pengawas Obat dan Makanan (BPOM) dengan pabrik pembuat obat. Metode ini dipilih dengan pertimbangan bahwa cara tersebut dianggap metode yang paling tepat dengan tingkat keamanan yang paling optimal.

c. Bila tidak ada instruksi khusus, obat dapat dibuang ke tempat sampah. Namun, sebelum membuang obat ke tempat sampah, ada beberapa hal yang harus dilakukan, antara lain: Informasi tentang obat tersebut harus dihilangkan, kemudian obat dikeluarkan dari kemasan aslinya. Hal ini dilakukan untuk melindungi identitas dan privasi mengenai kondisi kesehatan kita. Selain itu, hal tersebut juga bermanfaat untuk terhindar dari terjadinya penyalahgunaan oleh pihak-pihak yang tidak bertanggung jawab (misalnya penjualan kembali obat-obatan yang telah dibuang setelah dikumpulkan oleh pemulung).

d. Obat-obatan yang telah rusak atau kadaluarsa dicampur dengan air, garam, kotoran, pasir, ampas kopi, atau bahan-bahan lain yang tidak diinginkan. Hal ini untuk menghindari terjadinya pengambilan obat oleh orang lain (misalnya pemulung), anak kecil, hewan, dan sebagainya.

e. Letakkan obat-obatan yang akan dimusnakan dalam wadah tertutup, misalnya dalam kantung plastik atau wadah lainnya yang ditutup rapat dan disegel dengan kuat. Hal ini dilakukan sebagai upaya untuk mencegah obat tersebut bocor atau keluar dari kantong sampah. Selain itu juga untuk mencegah terjadinya penyalahgunaan.

f. Kemasan obat yang akan dimusnakan seperti botol yang sudah tidak terpakai harus dihilangkan dulu semua informasinya (misalnya label pada botol sirup). Lemasan obat tersebut dapat dibuang dengan cara 
terlebih dahulu dimasukkan ke dalam wadah yang tertutup (tidak tembus pandang), seperti trash bag, lalu tutup dengan rapat dan disegel dengan kuat. Untuk kemasan obat seperti strip dan blister, sebaiknya kemasan dirusak terlebih dahulu dengan cara merobek atau mengguntingguntingnya sebelum dimasukkan ke kantong sampah, untuk menghindari terjadinya penyalahgunaan oleh pihak-pihak yang tidak bertanggung jawab.

Adapun kegiatan penyampaian materi melalui penyuluhan dapat dilihat pada gambar 5 .

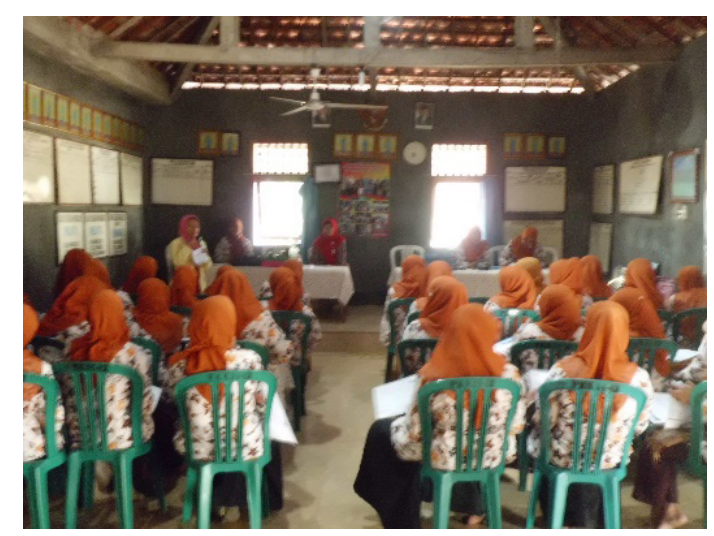

Gambar 5.

Penyampaian materi DAGUSIBU

\section{Sosialisasi tentang DAGUSIBU} diakhiri dengan sesi tanya jawab. Para peserta terlihat sangat antusias dalam kegiatan ini, dapat dilihat dari banyaknya peserta yang berkonsultasi tentang tata cara pengobatan yang tepat dan pengeloaan obat di rumah. Hal tersebut merefleksikan keingintahuan peserta untuk menambah wawasan dalam penggunaan obat yang cerdas, sehingga meningkatkan kesehatan masyarakat.

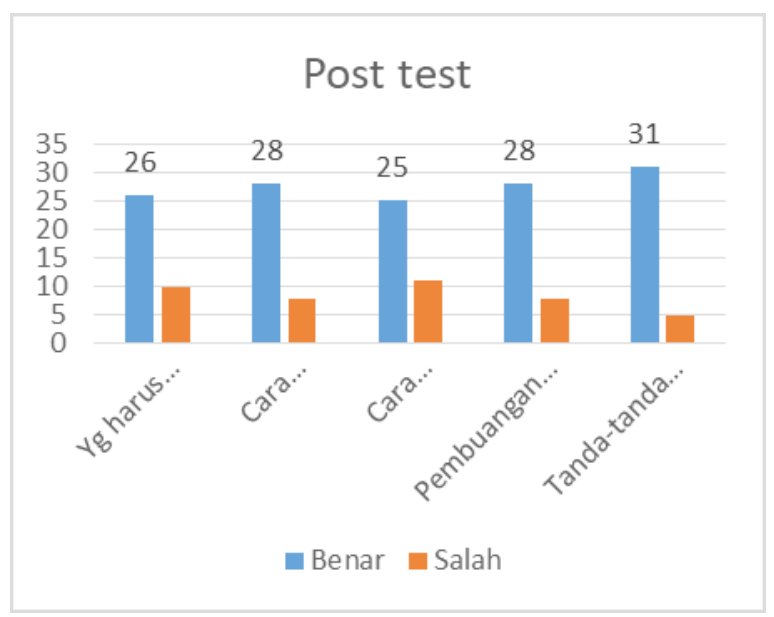

Gambar 6. Hasil Post test

Padaakhirkegiatan dilakukanevaluasi terhadap materi yang disampaikan, pada tahap evaluasi ini, peserta diminta mengisi questioner post-test DAGUSIBU. Hasil post test peserta dapat dilihat pada gambar 6. Selanjutnya untuk melihat keberhasilan kegiatan pengabdian kepada masyarakat ini dilakukan perbandingan nilai antara pretest dan post test peserta yaitu sebelum dilakukan penyuluhan dan setelah mendapatkan informasi dari pemateri. Adapun hasil perbandingan 
niali pre-test dan post test peserta dapat dilihat pada gambar 7 .

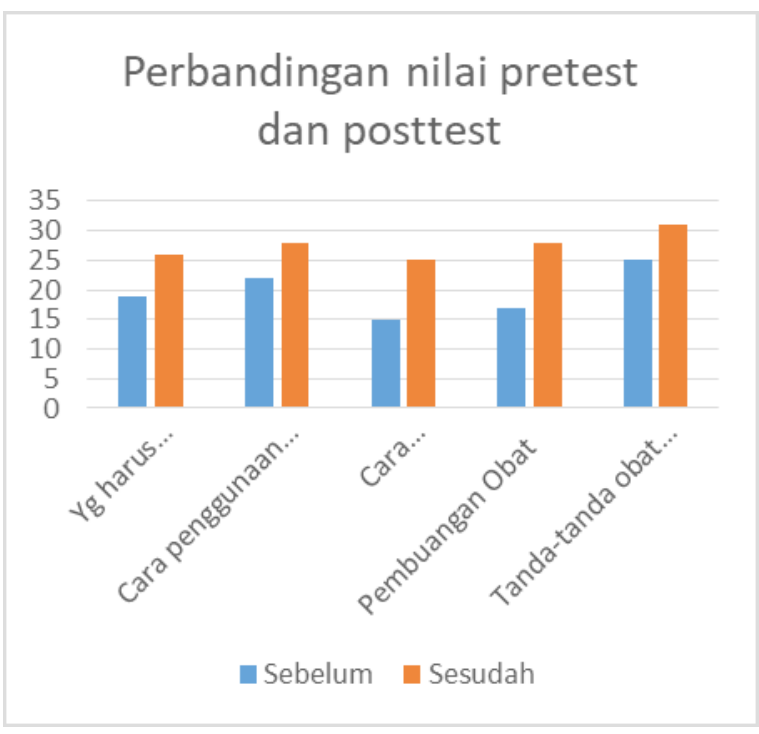

\section{Gambar 7.}

Perbandingan nilai pretest dan post test peserta.

Perbandingan nilai pretes dan posttest peserta (Gambar 7) menunjukkan terjadinya peningkatan yang signifikan mengenai pengetahuan tentang penggunaan dan pengelolaan obat yang benar oleh kader PKK desa Madulegi Kecamatan Sukodadi setelah diberikan penyuluhan mengenai DAGUSIBU.

Hasil pengabdian ini juga selaras dengan pengabdian yang terdahulu dilakukan oleh Lutfiyati et al (2017) yang menyebutkan bahwa kegiatan pengabdian masyarakat melalui metode penyuluhan mampu menambah pengetahuan peserta bagaimana mengelola obat dengan baik dan benar.

Penelitian yang terbaru dilakukan oleh (Purwidyaningrum et al., 2019). bahwa penyuluhan DAGUSIBU mampu memberikan efek kejelasan dan memberikan arahan yang jelas tentang penggunaan obat dan dibuktikan secara statistik terjadi peningkatan yang signifikan.

\section{KESIMPULAN DAN SARAN}

\section{Kesimpulan}

Dari hasil kegiatan pengabdian yang telah dilakukan terdapat peningkatan pengetahuan yang signifikan masyarakat terhadap penggunaan obat yang benar.

\section{Saran}

Perlu diadakan follow up kegiatan pengabdian untuk mengetahui perubahan perilaku masyarakat terkait penggunaan obat yang benar. 


\section{DAFTAR PUSTAKA}

Arrais, P. S. D., Fernandes, M. E. P., Pizzol, T. da S. D., Ramos, L. R., Mengue, S. S., Luiza, V. L., ... Bertoldi, A. D. (2016). Prevalence of self-medication in Brazil and associated factors. Revista de Saude Publica, 50(suppl 2), 1-11. https://doi.org/10.1590/S15188787.2016050006117

Candradewi, S. F., \& Kristina, S. A. (2017). Gambaran pelaksanaan swamedikasi dan pendapat konsumen apotek mengenai konseling obat tanpa resep di wilayah Bantul. Pharmaciana, 7(1), 41. https://doi.org/10.12928/pharmaciana.v7i1.5193

Dwi Ajeng Eli Ananda, Liza Pristianty, \& Hidajah Rachmawati. (2013). Hubungan Tingkat Pengetahuan dan Perilaku Swamedikasi Obat Natrium Diklofenak di Apotek. Pharmacy, $10(02)$.

Harahap, N. A., Khairunnisa, K., \& Tanuwijaya, J. (2017). Patient knowledge and rationality of self-medication in three pharmacies of Panyabungan City, Indonesia. Jurnal Sains Farmasi \& Klinis, 3(2), 186. https://doi.org/10.29208/jsfk.2017.3.2.124

Lutfiyati1, H., Fitriana Yuliatuti, \& Dianita, P. S. (2017). Pemberdayaan Kader PKK dalam Penerapan DAGUSIBU ( Dapatkan, Gunakan, Simpan, dan Buang ). (1), 9-14.

Maziyyah, N. (2015). Penyuluhan Penggunaan Obat Yang Benar (Dagusibu) Di Padukuhan Bakalan, Mlati, Sleman, Yogyakarta. Laporan Kegiatan Pengabdian Masyarakat, 49(236), 22-23.

Pons, E. D. S., Knauth, D. R., Vigo, Á., Mengue, S. S., Gadelha, C. A. G., Costa, K. S., ... De Carvalho, A. C. C. (2017). Predisposing factors to the practice of self-medication in Brazil: Results from the National Survey on Access, Use and Promotion of Rational Use of Medicines (PNAUM). PLoS ONE, 12(12), 1-12. https://doi.org/10.1371/journal. pone. 0189098

Purwidyaningrum, I., Peranginangin, J. M., Mardiyono, M., \& Sarimanah, J. (2019). Dagusibu, P3K (Pertolongan Pertama Pada Kecelakaan) di Rumah dan Penggunaan Antibiotik yang Rasional di Kelurahan Nusukan. Journal of Dedicators Community, 3(1), 23-43. https:// doi.org/10.34001/jdc.v3i1.782 
Restiyono, A. (2016). Analisis Faktor yang Berpengaruh dalam Swamedikasi Antibiotik pada Ibu Rumah Tangga di Kelurahan Kajen Kebupaten Pekalongan. Jurnal Promosi Kesehatan Indonesia, 11(1), 14. https://doi.org/10.14710/jpki.11.1.14-27

RISKESDAS. (2013). Skin substitutes to enhance wound healing. In Bakti Husada. https://doi. org/10.1517/13543784.7.5.803

Safitri, O. R. M. D. A. N. S. R. (2016). TINGKAT PENGETAHUAN OBAT COMMON COLD DI DESA THE INFLUENCES OF EDUCATION CBIA ( MOTHER ACTIVE LEARNING METHOD ) ON. Jurnal Manajemen Dan Pelayanan Farmasi, 6(1), 69-74.

WHO. (2012). The Pursuit of Responsible Use of Medicines: Sharing and Learning from Country Experience.

Yati, K., Hariyanti, \& Lestari, P. M. (2018). Pelatihan Pengelolaan Obat yang Tepat dan Benar di UKS Sekolah-. Jurnal SOLMA P-ISSN 2252-584X, 07(1), 42-49. 